\title{
Occult gallbladder carcinoma presenting as a primary ovarian tumor in two women: two case reports and a review of the literature
}

\author{
Yashwant Kumar $^{1 *}$, Alka Chahal ${ }^{3}$, Monika Garg ${ }^{3}$, Anjali Bhutani ${ }^{2}$
}

\begin{abstract}
Introduction: The ovary is a common site of metastasis from various organs. However, little is known about gallbladder carcinoma metastasizing to the ovaries and presenting as a primary ovarian tumor.

Case presentation: We report two cases of a metastatic gallbladder carcinoma which mimicked a primary ovarian tumor in a 35-year-old and a 62-year-old North Indian woman. Clinically, both our patients presented with abdominal masses without obvious signs and symptoms related to gallbladder carcinoma. Radiology suggested the possibility of a primary ovarian tumor with chronic cholecystitis and cholelithiasis. The gross features also mimicked a primary malignant ovarian tumor in the first case and a benign mucinous neoplasm in the second case. Exact diagnoses could only be made after thorough sampling from both the ovaries and gallbladder.
\end{abstract}

Conclusions: Gallbladder carcinoma with metastasis to the ovaries can mimic both malignant and benign primary ovarian tumors. Extensive cystic change in the ovary due to metastasis from gallbladder carcinoma has rarely been reported. A high index of suspicion and thorough sampling are essential to avoid misdiagnosis in such cases.

\section{Introduction}

Ovary is a relatively frequent site of metastasis from various organs especially pancreas and gastrointestinal tract. Rarely, the metastasis may precede detection of the primary site and may present as an ovarian tumor [1]. Metastasis from gallbladder to ovaries, though known, is rare with only few reports available in the English literature [2-9]. Some of these were initially misdiagnosed as a primary ovarian tumor. Lack of awareness or limited information may be the reasons for incorrect diagnosis in these cases. Therefore the unique features of occult gallbladder cancer going to ovary need to be explored and reported. Here we describe two such cases that were missed on initial examination. A review of literature has been carried out to search for the most important features which will aid in arriving at a correct diagnosis.

\footnotetext{
* Correspondence: yashwantk74@yahoo.com

${ }^{1}$ The Pine, Near Ashiana Regency, Chhota Shimla, Shimla -171002, India
}

\section{Case presentation}

Case 1

\section{Clinical findings}

A 35-year-old North Indian woman presented with abdominal pain and discomfort with loss of appetite and indigestion for one month. Systemic examination revealed abdominal distension and slight tenderness in her right hypochondrium along with palpable bilateral adnexal masses. There was no icterus, but mild elevation of serum bilirubin with normal liver enzyme levels. An ultrasound examination of her abdomen showed a diffusely thickened gallbladder with multiple calculi and bilateral large, solid-cystic adnexal masses suggestive of a primary ovarian malignancy with chronic cholecystitis and cholelithiasis. Her serum tumor marker CA-125 was raised $(267.4 \mathrm{U} / \mathrm{mL}$, reference range $0-36 \mathrm{U} / \mathrm{mL})$. Our patient underwent total abdominal hysterectomy and bilateral salpingo-oophorectomy with cholecystectomy. On exploration during surgery the gallbladder was found to be inflamed and adherent to part of omentum, 
therefore extended omentectomy was performed with removal of pelvic and retro-pancreatic lymph nodes.

\section{Histopathology findings}

Both her right and left ovaries were enlarged and measured $17 \times 8 \times 5 \mathrm{~cm}$ and $16 \times 7 \times 5 \mathrm{~cm}$, respectively. External surface of both was nodular (Figure 1a) and slicing revealed the parenchyma almost completely replaced by a tumor with involvement of hilum as well. The cut surface was multinodular and had a variegated appearance with both solid and cystic areas. Solid areas were well demarcated, soft to firm and pale-yellow in color. The cystic spaces were filled with mucinous material (Figure 1b). Bilateral fallopian tubes, uterus and cervix were normal.

Both the masses showed a similar morphology on microscopy. Solid areas were composed of irregular glands and nests infiltrating the loose stroma (Figure 1c). The tumor was reaching up to capsule and encroaching upon the surface. The glands were lined by large pleomorphic cells exhibiting high grade nuclear atypia. Cystic areas showed dilated spaces lined by malignant cells (Figure 1d). Bizarre tumor giant cells, occasional signet ring cells and atypical mitotic figures were noted. Large areas of infarction and necrosis were also seen. Normal ovarian stroma was identified in one of the sections only.

The gallbladder had a gangrenous appearance with diffusely hemorrhagic and thickened wall covered with slough on both the serosal as well as mucosal aspect (Figure $2 \mathrm{a})$. The lumen contained multiple mixed stones.

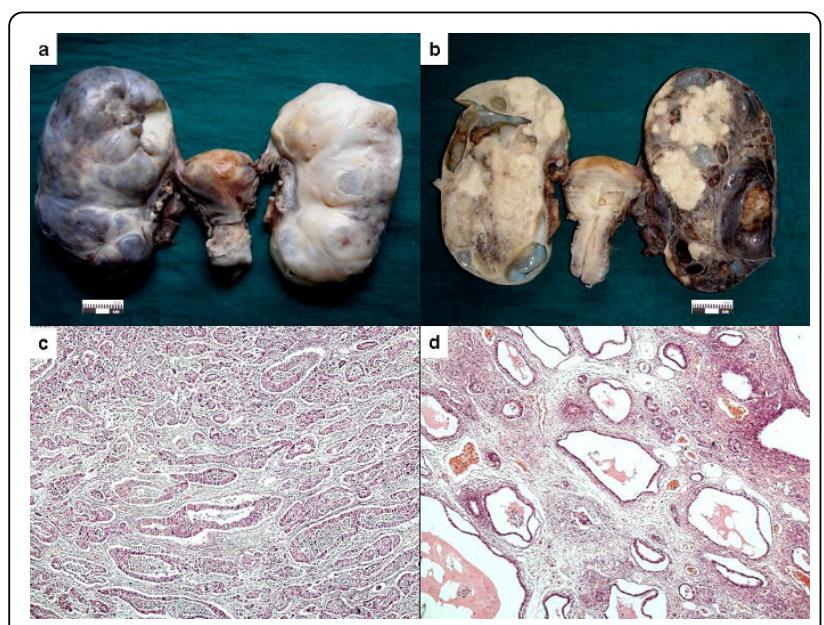

Figure 1 (A) Capsular surface of bilateral ovarian masses. Note the smooth looking but nodular outer surface. Also note size of both the masses compared to uterus. (B) Cut surface of a solid cystic growth with solid grey-white areas present in the form of nodular deposits. (C) On microscopy tumor glands were forming glands of variable size and shape. (D) Tumor tissue represented by large cystic spaces lined by flattened epithelium. Smaller glands are also present in between.
Besides extensive necrosis and hemorrhage, sections from viable areas showed an invasive adenocarcinoma with transmural involvement of the wall and overlying dysplastic epithelium (Figure 2b). Perineural invasion was also noted. The omentum and retro-pancreatic lymph nodes showed tumor metastasis in the form of pools of mucin infiltrating and dissecting the native tissue. The tumor cells were found to be floating within the mucin and many of them had a signet ring appearance.

\section{Case 2}

\section{Clinical findings}

A 62-year-old woman from a Northern part of India presented with complaints of pain and swelling in the abdomen and generalized weakness for a duration of four months. Routine biochemistry including liver function tests and hematological parameters were normal. A computed tomography (CT) scan of her abdomen showed two large masses arising from pelvis on either side of the uterus. The masses were reaching up to epigastrium and displacing gut loops anteriorly and towards right side. Both of them were largely cystic with well defined walls (Figure 3). Her gallbladder contained multiple stones and wall in the fundic region was thickened resembling calcification. There was no ascitis or pleural effusion and CA-125 was raised (148.2 U/mL). Radiological impression was cholelithiasis and bilateral ovarian tumor of benign nature. However, considering the age of our patient, size of the masses and raised CA-125 it was thought to be an ovarian malignancy and exploratory laparotomy was done for total abdominal hysterectomy with bilateral salpingo-oophorectomy and cholecystectomy. Intra-operative findings revealed bilateral cystic ovarian masses and a hard and solid gallbladder mass firmly adherent to surrounding tissue. Omental nodules were also noted and removed.

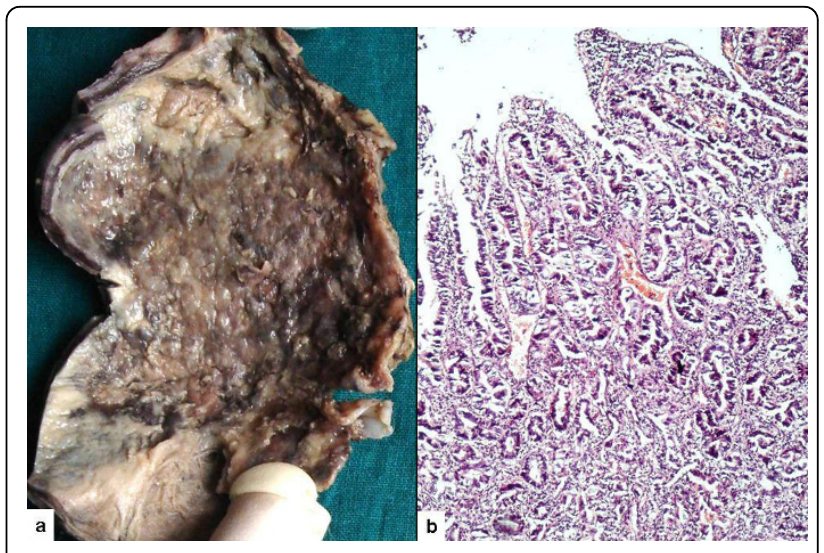

Figure 2 (A) Diffusely hemorrhagic and ulcerated gallbladder mucosa. No growth is apparent. (B) An invasive adenocarcinoma with dysplastic overlying epithelium. 


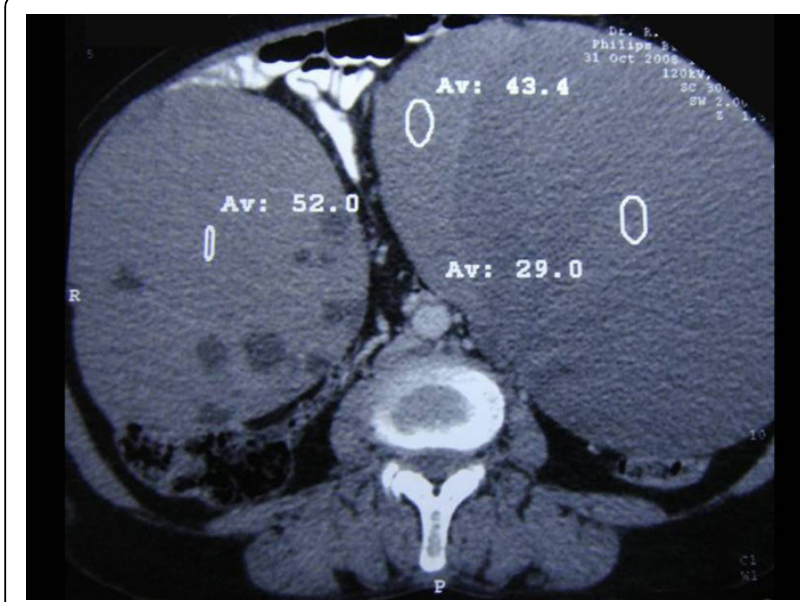

Figure $3 \mathrm{CT}$ scan of abdomen showing two large cystic masses arising from pelvis.

\section{Histopathology findings}

Bilateral ovarian masses were well encapsulated with right mass measuring $20 \times 18 \times 11 \mathrm{~cm}$ and left $18 \times$ $13 \times 10 \mathrm{~cm}$. Capsular surface of both revealed evenly distributed multiple tiny pinhead size excrescences (Figure 4a). Cut surface revealed multiloculated cystic tumor filled with thick and solidified gelatinous material as well as dull colored fluid (Figure 4b). The septae were papery thin, at places forming small cysts giving a spongy appearance. No solid areas were found in either of the masses even on serial slicing except two very small $0.5 \mathrm{~cm}$ diameter, subcapsular grey-white nodules. Her uterus showed an incidental $1.5 \mathrm{~cm}$ intra-mural leiomyoma in the fundic region. Her cervix, bilateral fallopian tubes and ovarian pedicles were normal.

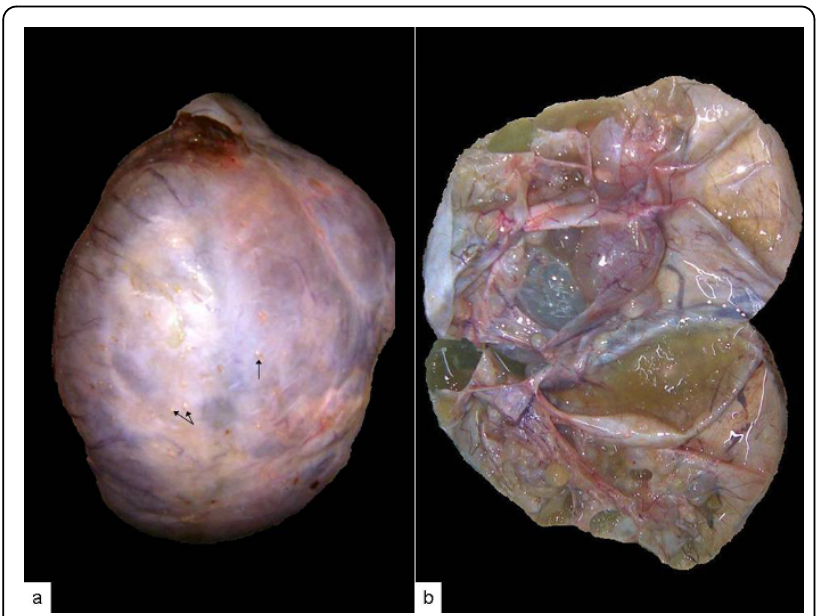

Figure 4 (A) Well encapsulated left ovarian mass. Note tiny pinhead size excrescences on the surface (arrow). (B) The cut surface resembling a multiloculated benign cystic tumor.

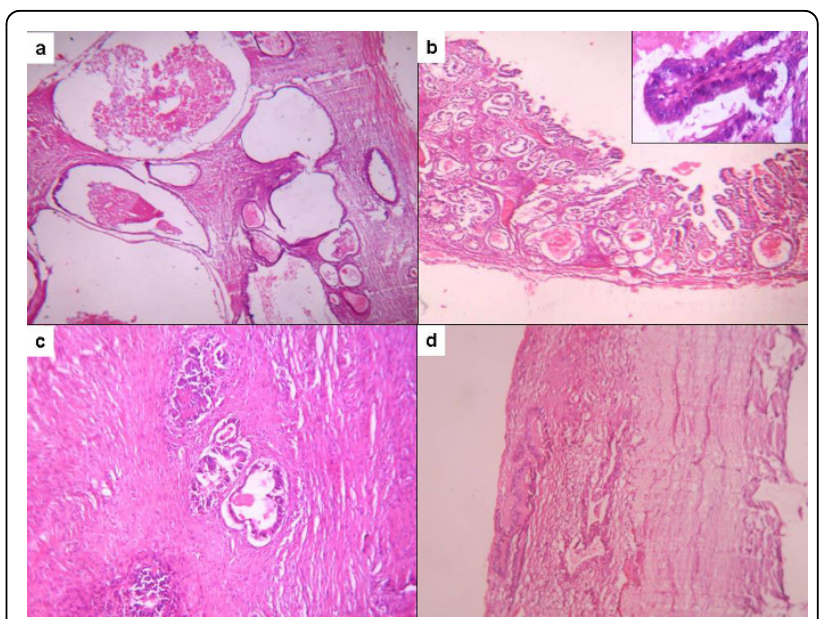

Figure 5 (A) Large cystic spaces lined by flattened epithelium and filled with acellular material. (B) Malignant tumor glands with back to back arrangement. Note marked atypia of cells within papillae (inset). (C) Irregular shaped glands within the desmoplastic stroma. (D) Surface implants.

On microscopy cystic spaces were lined by flattened epithelium and filled with acellular material (Figure 5a). On low power examination lining epithelium was flattened to columnar and appeared bland without any stratification or multilayering. Therefore the possibility of benign mucinous cystadenoma was initially proposed. The additional sections however revealed marked atypia of the lining epithelium. Two out of 23 sections taken from small subcapsular nodules showed atypically proliferating mucinous epithelium (Figure 5b). Few papillae were also seen lined by epithelial cells with marked atypia. Intervening stroma was scanty but few foci of infiltration by irregular shaped glands were identified

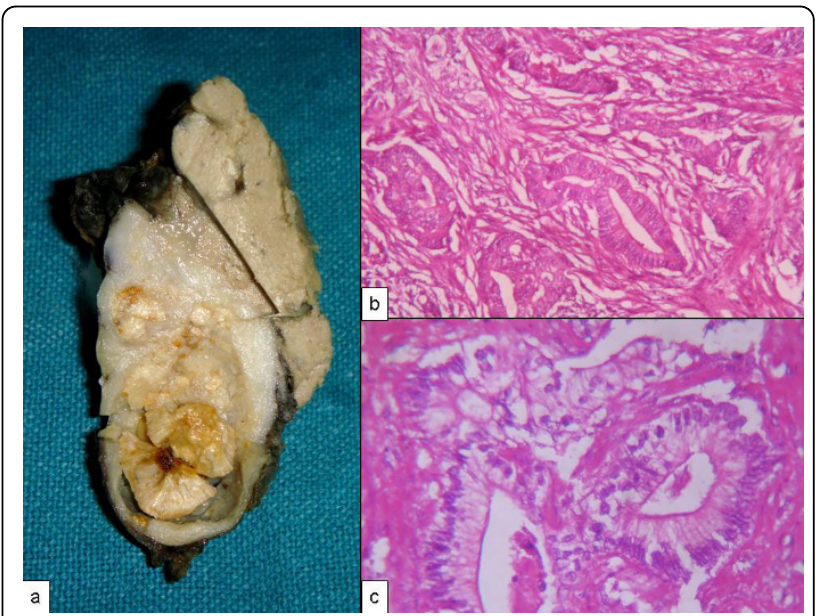

Figure 6 (A) Thickened gallbladder wall with a fragmented stone. (B) Well formed tumor glands within a desmoplastic stroma. The glands are lined by columnar cells with basally placed nuclei. 
(Figure 5c). Tiny excrescences present on the capsular surface showed tumor gland deposits (Figure 5d) supporting the possibility of a metastatic tumor. Uninvolved ovarian parenchyma was fibrous and contained hemosiderin laden and foamy macrophages.

The serosal surface of gallbladder was smooth and shiny. The lumen was impacted with a $1.3 \mathrm{~cm}$ diameter cholesterol stone. In the body region mucosa was ulcerated with variably thickened wall (Figure 6a). Microscopy showed a moderately differentiated adenocarcinoma (Figure 6b). Omental nodules showed metastatic tumor deposits with a similar morphology as in case 1 .

\section{Discussion}

The incidence of ovarian metastasis from different organs is nearly five to $15 \%$ [7]. Although a figure of $6 \%$ cases of gallbladder carcinoma with metastasis to ovary has been quoted by Albores-Saavedra [10], a description of only 19 such cases could be found in the literature (Table 1) [2-9]. Of these, eight cases presented with ovarian masses $[2,3,5,6,8,9]$ and clinico-radiological findings in five mimicked a primary ovarian tumor $[2,3,8]$. With a pre-operative radiological investigation, diagnosis could not be established in four cases [4-7] and few were misdiagnosed as primary ovarian tumor even on histology $[6,7]$.

Table 1 A summary of reported cases of gallbladder carcinoma with ovarian metastasis.

\begin{tabular}{|c|c|c|c|c|c|c|c|c|}
\hline \multirow[t]{2}{*}{ Author } & \multirow[t]{2}{*}{$\begin{array}{c}\text { No. } \\
\text { of } \\
\text { cases }\end{array}$} & \multirow[t]{2}{*}{$\begin{array}{l}\text { Age } \\
\text { (yrs) }\end{array}$} & \multirow[t]{2}{*}{$\begin{array}{l}\text { Clinical } \\
\text { presentation }\end{array}$} & \multirow[t]{2}{*}{$\begin{array}{l}\text { Detection } \\
\text { of primary/ } \\
\text { secondary }\end{array}$} & \multirow[t]{2}{*}{ Laterality } & \multirow[t]{2}{*}{ Size $(\mathrm{cm})$} & \multicolumn{2}{|l|}{ Histopathology of ovary } \\
\hline & & & & & & & Gross & Micro \\
\hline $\begin{array}{l}\text { Khunamornpong } \\
\text { et al.[2] }\end{array}$ & 8 & $47-83$ & $\begin{array}{l}\text { Pelvic mass, } \\
\text { abdominal } \\
\text { distension, } \\
\text { vaginal } \\
\text { bleeding, } \\
\text { hematochezia } \\
\mathrm{n}=1 \text { each } \\
\text { abdominal } \\
\text { pain, unknown } \\
\mathrm{n}=2 \text { each }\end{array}$ & $\begin{array}{l}\text { Primary first } \\
n=3 \\
\text { Simultaneous } \\
n=5\end{array}$ & Bilateral & $0.5-16.5$ & $\begin{array}{l}\text { Smooth external surface in } \\
\text { majority, cut surface } \\
\text { predominantly solid-cystic } \\
\text { or solid in some, cyst } \\
\text { content mucoid in majority }\end{array}$ & $\begin{array}{l}\text { All except } 1 \text { were } \\
\text { recognized as metastatic } \\
\text { tumors; initially diagnosis } \\
\text { was not appreciated in } 1 \\
\text { case. All had foci } \\
\text { indistinguishable from } \\
\text { primary surface epithelial } \\
\text { neoplasms }\end{array}$ \\
\hline $\begin{array}{l}\text { Young and Scully } \\
\text { [3] }\end{array}$ & 5 & $33-72$ & $\begin{array}{l}\text { Abdominal } \\
\text { pain } \\
\mathrm{n}=4 \\
\text { Pelvic mass } \\
\mathrm{n}=1\end{array}$ & $\begin{array}{l}\text { Primary first } \\
\mathrm{n}=1 \\
\text { Simultaneous } \\
\mathrm{n}=3 \\
\text { Ovarian first } \\
\mathrm{n}=1\end{array}$ & Bilateral & $2.5-13$ & $\begin{array}{l}\text { Lobulated external surface. } \\
\text { Cut surface in all except } 1 \\
\text { was nodular and solid }\end{array}$ & $\begin{array}{l}\text { Half of them were difficult } \\
\text { to diagnose and simulated } \\
\text { primary ovarian neoplasm }\end{array}$ \\
\hline Ayhan et al.[4] & 1 & 33 & $\begin{array}{l}\text { Abdominal } \\
\text { pain }\end{array}$ & Simultaneous & Unilateral & 3 & - & - \\
\hline Miyagui et al.[5] & 1 & 43 & Confusion & Simultaneous & Bilateral & 17 and 19 & $\begin{array}{l}\text { Cut surface compact } \\
\text { intermingled with cystic } \\
\text { areas containing yellow } \\
\text { gelatinous fluid }\end{array}$ & $\begin{array}{l}\text { Ovarian architecture } \\
\text { entirely replaced } \\
\text { neoplastic cells disposed } \\
\text { in alveolar and trabecular } \\
\text { patterns. Mucin \& signet } \\
\text { ring cells }\end{array}$ \\
\hline Jain et al.[6] & 1 & 45 & Pelvic mass & Simultaneous & Bilateral & - & - & Malignant cystic deposits \\
\hline Jarvi et al.[7] & 1 & 82 & $\begin{array}{l}\text { Abdominal } \\
\text { pain }\end{array}$ & Simultaneous & Bilateral & - & $\begin{array}{l}\text { Solid cystic masses with } \\
\text { focally roughened surfaces }\end{array}$ & $\begin{array}{l}\text { Bilateral benign serous } \\
\text { cystadenoma with } \\
\text { deposits of metastatic } \\
\text { adenocarcinoma }\end{array}$ \\
\hline Taranto et al.[8] & 1 & 52 & Pelvic mass & Primary first & Bilateral & 15 & - & $\begin{array}{l}\text { Difficult to distinguish } \\
\text { from a primary mucinous } \\
\text { adenocarcinoma of the } \\
\text { ovary even on histology }\end{array}$ \\
\hline $\begin{array}{l}\text { Majumdar et al. } \\
{[9]}\end{array}$ & 1 & 38 & $\begin{array}{l}\text { Abdominal } \\
\text { pain } \\
\text { and distension }\end{array}$ & Simultaneous & Bilateral & 13 and 8 & - & $\begin{array}{l}\text { Papillary pattern, cystic } \\
\text { spaces, extracellular mucin, } \\
\text { surface implants }\end{array}$ \\
\hline $\begin{array}{l}\text { Kumar et al. } \\
\text { (present study) }\end{array}$ & 2 & $\begin{array}{l}35 \\
62\end{array}$ & $\begin{array}{l}\text { Abdominal } \\
\text { pain and } \\
\text { distension }\end{array}$ & Simultaneous & Bilateral & $\begin{array}{l}17 \text { and } 18 \\
20 \text { and } 18\end{array}$ & $\begin{array}{l}\text { Case 1: Solid cystic masses } \\
\text { and gangrenous } \\
\text { gallbladder } \\
\text { Case 2: Entirely cystic, } \\
\text { multiloculated ovarian } \\
\text { masses filled with thick and } \\
\text { thin mucin }\end{array}$ & $\begin{array}{l}\text { Nodular growth with } \\
\text { infiltrative pattern. } \\
\text { Presence of surface } \\
\text { deposits, cellular atypia, } \\
\text { and infiltrative pattern }\end{array}$ \\
\hline
\end{tabular}


Similar to the present report, a majority of such patients had non-specific abdominal or pelvic symptoms (pain, distension, or mass). Jaundice or other symptoms related to gallbladder carcinoma were observed in only few cases $[2,6,9]$. Radiological features of malignancy were masked by chronic cholecystitis or cholelithiasis. Serological markers such as alkaline phosphatase, CA19-9, CEA, and CA125 were found to be variable at the time of metastases [2-4,6-9]. In both our patients CA-125 levels were raised, however CA19-9 was not assessed. A variable clinical presentation, radiology and serum markers make the appropriate histological diagnosis mandatory [3,11-13].

The morphological features, on histology of metastasis, may mimic not only malignant but also a benign ovarian tumor as observed in our patients. In the first case, the gallbladder was gangrenous and no obvious growth was apparent on gross examination. Microscopically, only a few tumor glands were noticed in one of the sections taken from the gallbladder. The origin of these glands could not be traced from these initial sections. The gallbladder therefore was re-grossed. Repeat sections taken revealed a tumor diffusely involving the gallbladder wall with overlying dysplastic epithelium. This along with a bilateral tumor, multinodularity, infiltrative pattern and presence of uninvolved tissue supported the possibility of a metastatic carcinoma rather than a primary malignancy in the ovaries.

The second case showed a full-fledged gallbladder malignancy. The ovarian masses, however, were completely cystic with no solid areas. The initial sections suggested possibility of a benign mucinous tumor. However, presence of focal atypia in the lining epithelium and a high index of suspicion, in view of presence of a gallbladder malignancy led to re-examination of the specimen. Tiny pinhead size elevations over the capsule (Figure 3b) and subcapsular nodules identified on second look revealed malignant glands, which supported the possibility of a metastatic tumor.

Table 2 Pathological features differentiating a secondary from primary ovarian tumor $[2,11,14,15]$

\begin{tabular}{|c|c|c|}
\hline Pathological features & Secondary & Primary \\
\hline \multicolumn{3}{|l|}{ Gross } \\
\hline Bilaterality & $\checkmark$ & \\
\hline Surface implants & $\checkmark$ & \\
\hline Multinodular growth & $\checkmark$ & \\
\hline Size $>10 \mathrm{~cm}$ & $\checkmark$ & $\checkmark$ \\
\hline Smooth tumor surface & & $\checkmark$ \\
\hline Mural nodule & & $\checkmark$ \\
\hline \multicolumn{3}{|l|}{ Micro } \\
\hline $\begin{array}{l}\text { Surface implants in the form of irregular/dilated/cystic/angulated/tubular glands/cell nests or single tumor cells within a } \\
\text { desmoplastic/hyalinized stroma }\end{array}$ & $\checkmark$ & \\
\hline $\begin{array}{l}\text { Infiltrative pattern (disorderly penetration of the stroma by small glands, tubules, or single cells, including signet-ring cells, } \\
\text { usually within a desmoplastic stroma) }\end{array}$ & $\checkmark$ & \\
\hline Growth in the ovarian hilum & $\checkmark$ & \\
\hline Foci of uninvolved ovarian tissue & $\checkmark$ & \\
\hline Mucin without epithelial cells on the tumor surface or the residual ovarian surface & $\checkmark$ & \\
\hline A predominantly cystic gross appearance with only few solid necrotic or hemorrhagic areas & $\checkmark$ & $\checkmark$ \\
\hline Grossly mucinous cyst contents & $\checkmark$ & $\checkmark$ \\
\hline Areas of a cribriform, villous, or solid growth & $\checkmark$ & $\checkmark$ \\
\hline Microscopic mucin extravasation into the stroma & $\checkmark$ & $\checkmark$ \\
\hline Benign or borderline-appearing areas (either with atypia only or with intraepithelial carcinoma) & $\checkmark$ & $\checkmark$ \\
\hline Focal endometrioid-like appearance & $\checkmark$ & $\checkmark$ \\
\hline Microscopic cysts, generally $>2$ mm & $\checkmark$ & $\checkmark$ \\
\hline $\begin{array}{l}\text { "Expansile" invasive pattern (sharply demarcated, multicystic or labyrinthine spaces lined by malignant-appearing epithelial } \\
\text { cells, with minimal or no recognizable intervening stroma, in an area exceeding } 10 \mathrm{~mm} \text { and at least } 3 \mathrm{~mm} \text { in any single } \\
\text { dimension) }\end{array}$ & & $\checkmark$ \\
\hline A complex papillary epithelial growth (branching papillae with epithelial stratification and little or no stromal support) & & $\checkmark$ \\
\hline $\begin{array}{l}\text { Intraluminal necrotic material (tumor cell karyorrhectic nuclear fragments, neutrophils, and acellular debris) in gland-cyst } \\
\text { lumens }\end{array}$ & & $\checkmark$ \\
\hline \multicolumn{3}{|l|}{ Immunohistochemistry } \\
\hline CK-7 & $\checkmark$ & $\checkmark$ \\
\hline CK-20 & $\checkmark$ & $\checkmark$ \\
\hline Dpc4 & $\checkmark$ & $\checkmark$ \\
\hline
\end{tabular}


In the literature a variety of features have been emphasized (Table 2) that may help to differentiate metastasis from a primary ovarian tumor $[2,11,14]$. Amongst these, the bilaterality, surface implants, multinodularity, infiltrative pattern, foci of uninvolved ovarian tissue, growth in the ovarian hilum, mucin without epithelial cells on the tumor surface and presence of signet ring cells are the most important clues for a metastatic adenocarcinoma. However, many of these features may be absent, especially if the metastasis presents as benign cystic mass. Although the immunohistochemistry can distinguish metastasis from other organs with respect of colorectal carcinoma $\left(\mathrm{CK} 7^{-} / \mathrm{CK} 20^{+}\right)$in contrast to ovarian primaries $\left(\mathrm{CK}^{+} / \mathrm{CK} 20^{-} / \mathrm{CK}^{2} 0^{+}\right)$, its role in metastasis from gallbladder is limited because of similar profile to that of primary ovarian mucinous tumors $[2,15]$. A thorough gross examination and adequate sectioning therefore are important in such cases.

Outcome in these cases is generally poor. However, adequate surgery with palliative treatment may prolong survival for few months. Therefore at the time of total abdominal hysterectomy and bilateral salpingo-oophorectomy with cholecystectomy presence of unusual findings such as a gallbladder mass, dense adhesions of the omentum and adjacent organs to the gallbladder, difficult dissection of the gallbladder from its liver bed should raise the suspicion of a carcinoma. A close evaluation of the extent of the disease should be carried out. Biopsy of any lymph node should be taken. Intraoperative ultrasound, intra-portal endoscopic ultrasound and frozen section all may be performed to assess the extent of the disease. In the presence of ascites, fluid should be obtained for cytology; otherwise, a peritoneal wash-out can be considered for cytology [16]. External radiation therapy with or without chemotherapy may provide some palliative benefit to these patients.

\section{Conclusions}

Gallbladder carcinoma should be added to the previously known list of origins of metastatic tumors to the ovary that can closely mimic primary ovarian mucinous tumors. Pathologists should maintain a high index of suspicion and adequate sampling should be done of ovarian masses especially if bilateral. In all bilateral mucinous tumors outer surface should be examined carefully for presence of tiny deposits. Knowledge of the extent to which gallbladder metastasis may mimic a primary ovarian tumor and its differentiating histological features may help in correct diagnosis and further management of the patient.

\section{Consent}

Written informed consent was obtained from both the patients for publication of this case report and any accompanying images. A copy of the written consent is available for review by the Editor-in-Chief of this journal.

\section{Author details}

${ }^{1}$ The Pine, Near Ashiana Regency, Chhota Shimla, Shimla -171002, India. 2Department of Pathology and Laboratory Medicine, Grecian Superspeciality, Cardiac and Cancer Hospital, Sector 69, SAS Nagar, Mohali, India. ${ }^{3}$ Department of Pathology, Maharshi Markandeshwar Institute of Medical Sciences and Research, Mullana, Ambala Haryana, India.

\section{Authors' contributions}

YK designed, carried out acquisition and analysis of data and drafted the manuscript. $A C$ and $A B$ helped in drafting of manuscript and given their valuable suggestions, MG provided the images. All the authors read and approved the final manuscript.

\section{Competing interests}

The authors declare that they have no competing interests.

Received: 21 October 2009 Accepted: 30 June 2010

Published: 30 June 2010

\section{References}

1. Petru E, Pickel M, Heydarfadai M, Lahousen M, Haas J, Schaider H, Tamussino K: Nongenital cancers metastatic to the ovary. Gynecol Oncol 1992, 44:83-86.

2. Khunamornpong $S$, Lerwill MF, Siriaunkgul $S$, Suprasert $P$, Pojchamarnwiputh S, Chiangmai WN, Young RH: Carcinoma of extrahepatic bile ducts and gallbladder metastatic to ovary. A report of 16 cases. Int J Gynecol Pathol 2008, 27:366-379.

3. Young $\mathrm{RH}$, Scully RE: Ovarian metastases from carcinoma of the gallbladder and extrahepatic bile ducts simulating primary tumors of the ovary. A report of six cases. Int J Gynecol Pathol 1990, 9:60-72.

4. Ayhan A, Guney I, Saygan-Karamursel B, Taskiran C: Ovarian metastasis of primary biliary and gallbladder carcinomas. Eur J Gynaecol Oncol 2001, 22:377-378.

5. Miyagui T, Luchemback L, Teixeira GH, de Azevedo KM: Meningeal carcinomatosis as the initial manifestation of a gallbladder adenocarcinoma associated with a Krukenberg tumor. Rev Hosp Clin Fac Med Sao Paulo 2003, 58:169-172.

6. Jain V, Gupta K, Kudva R, Rodrigues GS: A case of ovarian metastasis of gall bladder carcinoma simulating primary ovarian neoplasm: diagnostic pitfalls and review of literature. Int J Gynecol Cancer 2006, 16:319-321.

7. Jarvi K, Kelty CJ, Thomas WE, Gillespie A: Bilateral ovarian metastases from carcinoma of the gallbladder. Gynecol Oncol 2006, 103:361-362.

8. Taranto AJ, Lourie R, Lau WF: Ovarian vascular pedicle sign in ovarian metastasis arising from gall bladder carcinoma. Australas Radiol 2006, 50:504-506.

9. Majumdar K, Singh DK, Kaur S, Rastogi A, Gondal R: Papillary adenocarcinoma gallbladder with simultaneously detected bilateral ovarian metastasis: a case report. Internet J Gynecol Obst 2008, 9:1.

10. Albores-Saavedra J: Atlas of Tumor Pathology (Second Series). Armed Forces Institute of Pathology, Washington 1986.

11. Lee KR, Young RH: The distinction between primary and metastatic mucinous carcinomas of the ovary gross and histologic findings in 50 cases. Am J Surg Pathol 2003, 27:281-292.

12. Ronnett BM, Kurman RJ, Shmookler BM, Sugarbaker PH, Young RH: The morphologic spectrum of ovarian metastases of appendiceal adenocarcinomas: a clinicopathologic and immunohistochemical analysis of tumors often misinterpreted as primary ovarian tumors or metastatic tumors from other gastrointestinal sites. Am J Surg Pathol 1997, 21:1144-1155.

13. Young $\mathrm{RH}$, Hart WR: Metastases from carcinomas of the pancreas simulating primary mucinous tumors of the ovary. Am J Surg Pathol 1989, 13:748-756.

14. Seidman JD, Kurman RJ, Ronnett BM: Primary and metastatic mucinous adenocarcinomas in the ovaries. incidence in routine practice with a 
new approach to improve intraoperative diagnosis. Am J Surg Pathol 2003, 27:985-993.

15. Vang R, Gown AM, Barry TS, Wheeler DT, Yemelyanova A, Seidman JD, Ronnett BM: Cytokeratins 7 and 20 in primary and secondary mucinous tumors of the ovary: analysis of coordinate immunohistochemical expression profiles and staining distribution in 179 cases. Am J Surg Pathol 2006, 30:1130-1139.

16. Shiwani MH: Surgical management of gall bladder carcinoma. J Pak Med Assoc 2007, 57:87-90.

doi:10.1186/1752-1947-4-202

Cite this article as: Kumar et al:: Occult gallbladder carcinoma

presenting as a primary ovarian tumor in two women: two case reports and a review of the literature. Journal of Medical Case Reports 2010 4:202.

\section{Submit your next manuscript to BioMed Central} and take full advantage of:

- Convenient online submission

- Thorough peer review

- No space constraints or color figure charges

- Immediate publication on acceptance

- Inclusion in PubMed, CAS, Scopus and Google Scholar

- Research which is freely available for redistribution

Submit your manuscript at www.biomedcentral.com/submit 